\title{
Carolina Sanabria. Ofelia fementida: Transescrituras desde la literatura, la pintura, el cine. Barcelona: Laertes, 2019, 211 páginas
}

Conxita Domènech

Domènech, C. (2022). Carolina Sanabria. Ofelia fementida: Transescrituras desde la literatura, la pintura, el cine. Barcelona: Laertes, 2019, 211 páginas. Revista de Filología y Lingüística de la Universidad de Costa Rica, 48(1), e48063. doi: https://doi.org/10.15517/rfl.v48i1.48063

\section{(9) $\mathbb{P Q \Theta \Theta}$}

Doi: https://doi.org/10.15517/rfl.v48i1.48063

URL: https://revistas.ucr.ac.cr/index.php/filyling/index 
Revista de Filología y Lingüística de la Universidad de Costa Rica

ISSN: 0377-628X

ISSN: 2215-2628

filyling@gmail.com

Universidad de Costa Rica

Costa Rica

\section{Carolina Sanabria. Ofelia fementida: Transescrituras desde la literatura, la pintura, el cine. Barcelona: Laertes, 2019, 211 páginas}

Domènech, Conxita

Carolina Sanabria. Ofelia fementida: Transescrituras desde la literatura, la pintura, el cine. Barcelona: Laertes, 2019, 211 páginas

Revista de Filología y Lingüística de la Universidad de Costa Rica, vol. 48, núm. 1, e48063, 2022

Universidad de Costa Rica, Costa Rica

Disponible en: https://www.redalyc.org/articulo.oa?id=33268016001

DOI: https://doi.org/10.15517/rfl.v48i1.48063

\section{(c) (1) $\Theta(9$}

Esta obra está bajo una Licencia Creative Commons Atribución-NoComercial-SinDerivar 3.0 Internacional. 


\title{
Carolina Sanabria. Ofelia fementida: Transescrituras desde la literatura, la pintura, el cine. Barcelona: Laertes, 2019, 211 páginas
}

\author{
Conxita Domènech \\ Universidad de Wyoming, Laramie, Wyoming, Estados \\ Unidos \\ cdomenec@uwyo.edu \\ (iD) https://orcid.org/0000-0002-0480-2970

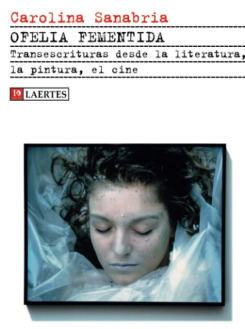

DOI: https://doi.org/10.15517/rfl.v48i1.48063

Redalyc: https://www.redalyc.org/articulo.oa?

Sanabria Carolina. Ofelia fementida: Transescrituras desde la literatura, la pintura, el cine. 2019. Barcelona. Laertes. 211pp.

No solo los protagonistas de las obras shakesperianas han cautivado la atención de autores, artistas y directores, también los personajes secundarios creados por William Shakespeare (1564-1616) han reaparecido en textos, cuadros y filmes. Ofelia -personaje secundario de La tragedia de Hamlet, principe de Dinamarca (1598-1602)- ejemplifica esta reaparición. Aunque la noble danesa interviene poco en el transcurso de la tragedia, su imagen se repetirá en numerosas ocasiones, sobre todo, a partir del siglo XIX. Carolina Sanabria se vale de la danesa, hija de Polonio y hermana de Laertes, para mostrar las transescrituras, las adaptaciones, las transmutaciones y los trasvases intersemióticos de una imagen fácilmente reconocible, pero que a un público poco informado sobre la obra shakesperiana y sobre la pintura decimonónica le costaría asociar con Ofelia. La autora no estudiará al personaje en sí, tampoco analizará su muerte -no escenificada en la obra original-; más bien, examinará una imagen en constante movimiento, que progresa y que se independiza de la tragedia shakesperiana. En Ofelia fementida: Transescrituras desde la literatura, la pintura, el cine, Sanabria muestra magistralmente que el personaje inicial ha evolucionado hasta obtener autonomía propia y se ha metamorfoseado en una nueva Ofelia o, incluso, en las muchas Ofelias de la pintura y del cine.

Aunque Ofelia pertenece al mundo literario, Sanabria se centra, especialmente, en la pintura, primero, y en el cine, después. No obstante, al comienzo del primer capítulo, la autora sitúa a Ofelia dentro de su propia obra y se detiene en su trágica muerte - un suicidio por ahogo o una caída accidental en el río-. Sin duda, la muerte de Ofelia se asocia con el ambiente natural e incorpora matices mitológicos que se remontan a la época clásica. La imagen final que queda de Ofelia se origina con el anuncio de su defunción por parte de la reina Gertrudis -la madre de Hamlet-, quien le relata a Laertes la muerte de su hermana. Más estético que dramático, el parlamento poético y visual de Gertrudis inicia la imagen lírica de una Ofelia muerta. A lo largo del volumen, Sanabria llamará a esa imagen una écfrasis a la inversa: una descripción sublime del entorno natural y de una Ofelia hermosa, frágil, virtuosa, inocente y representante del ideal femenino romántico.

El primer capítulo trata las pinturas de Ofelia durante el siglo XIX. Mientras a los pintores románticos les fascinaba plasmar el sufrimiento y la inestabilidad mental o la locura de Ofelia, a los prerrafaelitas -con John Everett Millais (1829-1896) a la cabeza- les interesaba pintar a la mujer ideal, es decir, buscaban el arte por 
arte. Así como el parlamento de Gertrudis desarrollaría el interés del público por la enamorada de Hamlet, la "Ofelia" (1852) de Millais estrena la imagen popular del personaje shakesperiano. En el río y rodeada de flores, a la Ofelia muerta de Millais se la imitaría y se la parodiaría, una y otra vez, hasta convertirse en un producto de masa para el mundo del entretenimiento. A partir de entonces, Ofelia se establece como la heroína de Shakespeare ilustrada con mayor frecuencia en la pintura, la litografía y el dibujo para ediciones de textos. Además de la Ofelia de Millais, Sanabria describe hábilmente otras pinturas decimonónicas del personaje femenino de Shakespeare: "La muerte de Ofelia" (1844) de Eugène Delacroix, "La joven mártir" (1855) de Paul Delaroche, "Ofelia tejiendo sus guirnaldas" (1884) de Richard Redgrave y "Ofelia" (dos pinturas: una de 1889 y otra de 1894) de John William Waterhouse, entre otras.

El segundo capítulo se distancia aún menos de la tragedia shakesperiana y Sanabria estudia con detalle los filmes deudores o en relación directa con la obra de teatro - Hamlet constituye el texto de Shakespeare que se ha adaptado en más ocasiones al cine y a la televisión-. Las versiones más apegadas a la tragedia conservan las características preeminentes de las pinturas decimonónicas: una Ofelia desvaída, generosos ropajes, cabellos largos y en desorden, flores, el sauce y la disposición del cuerpo en las aguas. Por un lado, la primera adaptación fílmica se remonta básicamente a los orígenes del cine: El duelo de Hamlet (1900) de Clément Maurice. Por otro lado, la primera recreación homónima completa de Hamlet fue dirigida por Hay Plumb en 1913. Pese a que cada director le da un enfoque y un estilo determinado, todos los trasvases cinematográficos recogen indirectamente la visualidad victoriana de Ofelia y de su muerte.

Sanabria continúa con el cine y con los motivos ofélicos en el tercer y último capítulo. Sin embargo, abandona los filmes que siguen textualmente la obra teatral para analizar productos fílmicos y audiovisuales contemporáneos de distinto formato que se alejan de las adaptaciones fieles: películas, cortometrajes, series televisivas como Vértigo (1958) de Alfred Hitchcock - considerado por James M. Vest un Hamlet moderno-, Twin Peaks (1990-1991) de David Lynch -el primer plano del cadáver de Laura Palmer es expuesto por la autora en la portada del presente volumen-, La pasión de Nuestra Señora (1998) de la costarricense Hilda Hidalgo, Las vírgenes suicidas (1999) de Sofia Coppola, Despertares del pasado (2002) de Michael Petroni y Melancolía (2011) de Lars von Trier, así como videoclips y cómics.

En Teoría y estética de la novela (1975), Mijaíl Bajtín afirma que la imagen de don Quijote se ha reacentuado en múltiples ocasiones y de muy diferentes maneras. Carolina Sanabria no utiliza el término reacentuación, ni estudia al protagonista del Quijote. En Ofelia fementida: Transescrituras desde la literatura, la pintura, el cine, la autora utiliza los términos transescritura, adaptación, transmutación y trasvase, y estudia a la noble danesa de Hamlet. Con todo, el resultado de Bajtín y de Sanabria se asemejan: las imágenes de don Quijote y de Ofelia, respectivamente, continúan desarrollándose incluso después del momento de su creación. Estas imágenes son identificadas hasta por aquellos que no han leído ni visto representada la obra. Es más: pocos conectarían a Laura Palmer de Twin Peaks con Ofelia. Carolina Sanabria nos muestra esa y otras conexiones en un libro cuidado hasta el más mínimo detalle. Y demuestra, con gran destreza, que un personaje marginal se convierte en un leitmotiv de la pintura victoriana y se consolida en un motivo fértil de los medios audiovisuales. 